\title{
FHIT wt Allele
}

National Cancer Institute

\section{Source}

National Cancer Institute. FHIT wt Allele. NCI Thesaurus. Code C49384.

Human FHIT wild-type allele is located in the vicinity of 3p14.2 and is approximately 1499 $\mathrm{kb}$ in length. This allele, which encodes bis(5'-adenosyl)-triphosphatase protein, is involved in the hydrolysis of P1-P3-bis(5'-adenosyl) triphosphate. FHIT gene dysfunction is associated with human cancers including carcinomas of the cervix, esophageus, lung, kidney, and stomach. 